\title{
Financing decisions of Migrant Family Businesses: The case of a Ghanaian-owned shop in Kent.
}

\author{
Bernard Boateng*, Professor Claire Seaman* and Dr Mauricio Silva** \\ * Queen Margaret Business School, Queen Margaret University, Edinburgh EH21 6UU \\ ** Glasgow Caledonian University
}

Keywords: Finance opportunities, Migrant entrepreneurs, entrepreneurship, financing decisions, Social Network Theory, and family norms and culture, Ghanaian businesses.

\begin{abstract}
The analysis of new enterprise funding and the financial strategies once in operation has been usually associated to mainstream sources of finance for which there is a standard quantitative method of analysis that relies on readily available information such as interest rates, credit risk analysis, collateral and guarantees, business and sector performance metrics among others. These variables are usually considered at the detriment of other qualitative factors that are difficult to measure and adapt to the rational analysis methodologies generally used and accepted by financial markets and institutions: these include but are not limited to the influence of family ties, cultural traditions, social networks, human capital, and individual attitudes towards money management and financial institutions. Thus we can hypothesise that the influence of social and cultural elements will tend to be more nuanced when the financial decision-making process within the realm of an immigrant family business with transnational social networks and distinct financial goals.
\end{abstract}

The aim of the paper is to share the preliminary findings of a study on the social and cultural factors influencing the financial decision making process of Ghanaian migrant family businesses in the UK. The overarching goal of the research project is to deepen our understanding of immigrant Ghanaian family businesses in the UK and the strategies they adopt when interacting with mainstream financial institutions and informal sources of funding to start up and manage their ventures.

The data was obtained through face-to-face interviews with a Ghanaian shop owner in Kent and her observations and thoughts on the process of making financial decisions and developing their enterprise. This was analysed through the prism of Social Network theory and focused on influences such as family, cultural and social factors. The main elements identified as having perceptible yet varying effects on the business owner's decision making included but were not limited financial decisions being influenced to family, cultural, social networks, and individual attitudes towards mainstream institutions. Significantly, 'Family ties and Influence' was the factor identified as having the most influence in the financial decision making process.

The key finding of this initial research exercise was that 'non-rational' drivers of financial decision-making were skewed towards an internally generated process unrelated to commonly accepted business growth strategies. This is of course a very limited finding as the case study 
by definition signifies the information is insufficient to support a clear conclusion; however the next phase of the research exercise should provide deeper and richer data for analysis.

\subsection{INTRODUCTION}

The UK can boast of various platforms and services that have been strategically designed to help budding migrant and/or family businesses. Some of these platforms include seed enterprise investment scheme, research and development tax credits, innovation vouchers and the FedEx small business grant (Smallbone et al, 2003: Lassale,2018). As to whether businesses operating in the UK are taking advantage of some of these services to grow will be explored by this paper. There is evidence to suggest that economic migrants in host countries will rely on different levels on their migrant networks to start their economic activities (Silva, 2013: Haug, 2008: Marti et al, 2017). This makes the social network of the business owner an important basis for their business decisions. The 'nodes' and 'relationships' that may have an influence on the finance decision making of the migrant family business was integral in the analysis of this paper (Borgatti and Halgin, 2011).

Research on financial decisions of businesses has mostly focused on standard economic variables such as interest rates, availability of financial products, collateral availability and credit worthiness all known as 'rational' factors given their underlying assumptions (Akbar, 2013). Although the above mentioned factors are important especially with mainstream financial institutions, it is worth noting that financial decision making cannot be exhaustively explained with the reasons mentioned above (Akbar, 2013). Other 'behavioural' factors such as family norms, socio-cultural influences and network links amongst others may also play an important role in the financial decision making processes especially when dealing with financial decisions of micro, small and medium enterprises. Also in cases where 'rational' information is not available, these 'behavioural' factors may serve to provide researchers with a better understanding of how migrant, unbanked or financially excluded firms make decisions in the new environment they may find themselves (Naldi, Nordqvist, Sjo berg, \&Wiklund, 2007 as cited by Sarbah and Wen, 2013).

The range of factors that influence the financial decision-making process of family-owned and operated SMEs extends beyond the 'rational' to include the 'behavioural' driven by economic goals that differ from those of non-family firms(Vandemaele and Vancanteren,2015). 
The financial-decision making processes even becomes more complex in the case of immigrant family businesses as the resources and challenges that come with settling in a new country are added to the family dynamics of managing and operating a business venture and therefore the need for all these factors to be holistically examined.

With all these dynamics and complexities that may drive financial decisions and support programs for migrant family businesses in mind, certain governments especially the UK government has created finance support initiatives for migrant entrepreneurs in order to stimulate employment and boost economic growth(Santos and Silvester, 2016). However, it is important to mention that these opportunities are sometimes deliberately ignored for reasons that are unknown to the policy makers of such facilities and therefore holistically understanding financing decision making processes in such a scenario will help in carving facilities and policies that are more effective and relevant.

Research has suggested that migrant family businesses may be important contributors to the UK economy's job creation and economic development (Santos and Silvester, 2016).Therefore, taking the time to understand the operations of these migrant family businesses and finding their needs will help to boost the growth and development of that sector. Despite the importance of micro, small and medium businesses, a World Bank study has found that about $90 \%$ of small enterprises have stated that one of the main obstacles to the effective running of their business is access to finance (Parker and Steel, 1995:World Bank, n.d as cited by Jones et al, 2015). It is also worth-noting that to properly understand what migrant family businesses perceive as obstacles it may help to first understand how they make financial decisions.

This article presents the preliminary findings of a research project focused on providing a better understanding of the financial decision-making processes of Ghanaian family businesses operating in the UK. Specifically, the article aims to discuss current progress against the following objectives.

1. To identify the key factors influencing the financial decision making process of a Ghanaian migrant family business in Kent within the framework of Social Network Theory

2. To identify any other behavioural drivers that may influence decision-making in order to meet business, family, personal and long-term aspirations. 
The objectives above when realised will lead to the following benefits;

- Deepening research in the area of Ghanaian family business financial decisions.

- Helping in designing micro-finance products and services for family businesses.

- Helping in designing business-support products and systems for African businesses in general especially those operating in the UK.

- Helping in improving the financial strategies of family businesses and subsequently effectively managing the cash flow and growth of such businesses.

\subsection{IMMIGRANT FAMILY BUSINESS OWNERS}

The literature on financing of businesses has mostly concentrated on small and medium enterprises, corporate institutions and non-family businesses usually at the detriment of research in the area of family business financing decisions (Motylska-Kuzma, 2017).This section of the paper will therefore look at the financial trends of SMEs and migrant businesses vis-a-vis how 'family' and 'migration' dynamics can impact their financial decisions.

\subsection{Financial Decisions for Migrant Micro businesses}

Effective decision-making and access to funding and other financial services (insurance, payments, overdrafts, etc.) are critical to the survival and growth of all businesses. It is more critical in the case of immigrant businesses that require adequate financing in order to survive economically in a new environment (Fatoki, 2014). How migrants engage with mainstream financial institutions and their living experiences of raising money is important to many aspects of their integration into a new community. There is the need to understand the migrants' perception about their ability to raise funds from formal sources such as banks and how these drive their financial decisions (Altinay and Altinay, 2008).

Research in 2011 examining migrant businesses in Germany indicated (from a survey of 234 entrepreneurs in Germany in the year 2006 and online questionnaires for 2250 entrepreneurs from nine countries), that immigrant businesses were more likely to be denied credit or were awarded relatively smaller loans relative to their German counterparts(i.e control sample of 750)(Bruder et al, 2011). This study found this had to do mostly with differences in risk factors and financial relationships with banks and not with ethnicity or national origin, although these 
type of experiences have been found to create a sense of exclusion amongst members of minority communities. The goal of the current exercise is to determine whether immigrant businesses in the UK (in particular of Ghanaian origin) are also susceptible to framing their financial decision-making process within this narrative of exclusion and miss out on the opportunities that local business owners of similar characteristics have available to them.

The research by Santos and Silvester (2016) suggests that the UK financial system is itself an inhibitor to finance access for migrant businesses. This is because they found that $37 \%$ of migrant entrepreneurs they interviewed in London had financed the start-up of their businesses personally because they could not transfer their credit history to the UK. This made it extremely difficult for them to get bank loans and other credit products. Additionally, most of the entrepreneurs also mentioned that although they were aware of some government schemes to help entrepreneurs, these schemes were mostly reserved for UK citizens (Santos and Silvester, 2016). Research in migrant ethnic minority businesses has also found they use substantial amounts of internally generated capital in the start up and running of their businesses due to 'how expensive 'it is to access external sources of finance (Evans, 2016).

Amongst immigrant businesses, Ghanaian businesses as well as most African businesses operating in the UK have also been found to be disadvantaged in terms of enterprise development, revenue growth and financial access opportunities as compared to Indian, Pakistani, Asian and other EU enterprises (Nwankwo, 2005). The opportunities and structures the UK government offers for enterprise development do not have an equal reach within migrant communities and further research is needed into whether this is a business or part of social and cultural trends that influence the financial decision making process of Ghanaian entrepreneurs in the UK.

It is important to note that mainstream external sources of finance are not necessarily a priority for small and medium-sized enterprises. Research by Hughes (1997)analysed trends in the financing of smaller businesses in the UK concluded that outside equity was unimportant to small firms, even to those experiencing rapid growth. Additionally, the findings suggested that even loans secured by these small firms were significantly short term ones which is in his view consistent with the pecking order hypothesis of raising funds. The research also suggested that the financial structure of SMEs usually reflected the wishes and strategies of their owners as well as the constraints placed upon them by their suppliers of finance. In other words, there are 
both internal and external pressures in the adoption of a financial strategy. In the case of immigrant businesses, the trends can be analysed in relation to social networks that may help to explain how financial decision strategies evolve within a small migrant family business.

The values and/or principles of these family or migrant small scale businesses may be a limiting factor in accessing finance. Family norms, attitudes, behavioural intentions and perceived behavioural control have been discussed as integral factors in the decision making process of finance choices of family businesses (Koropp et al, 2014).

The ethnicity of migrant businesses adds an extra layer of complexity to the issue of financial decision-making. Generally, access to finance has been cited as one of the most significant challenges facing ethnic minority and migrant businesses (Bates, 2011as cited by Carter et al, 2015). Although the research in the UK has been very limited, some findings suggest that ethnic minority immigrant businesses have varying experiences in their strife to access internal and external finance sources (Fraser, 2009; Ram et al., 2002 as cited by Carter et al, 2015; Seaman et al, 2014). It is important to determine the added influence of ethnicity to the migrant business owner in terms of the perception of opportunities available and how those influence their long- and short-term financial strategies.

Outside of the UK there have been many research efforts in an attempt to unravel the dynamics of immigrant SMEs. Fatoki (2014) looked at access to finance choices by migrant entrepreneurs in Johannesburg Central District and concluded that the major sources of finance for immigrant entrepreneurs during especially start-ups are the owner's contribution and that of his family and friends. The paper also asserted that the use of debt finance from commercial banks, suppliers and government agencies were limited and also financial support from friends and family seems to decline as immigrant entrepreneurs become established. Upon examination there is clearly a need to address the influence or otherwise of the networks of the business owner in his/her finance decision making process which this paper tried to understand.

In another non-UK research example, an article that examined a sample of Greek small and micro firms self-funding strategies and how their finance preferences concluded that firms heavily relied on their own funds and could not raise new equity outside the family. Again the researchers did not indicate whether the close family of business owner also had any effect or influence in their financial decision making process (Daskalakis and Jarvis, 2013). 
Hussain and Matlay (2007) identified family and close network associates of both ethnic minority businesses and white owners as main and preferred source of finance. This was ascertained in a comparative study that looked at their preference of finance to run their businesses. Again this paper could not indicate whether these family and networks were directly or indirectly part of the finance decision making pattern of the business owners in question.

\subsection{Framework for analysis}

A firm's financing strategy will mostly look at the composition of its sources of finance and what prompts it into deciding which one(s) to use.

The financial growth cycle which was proposed by Berger and Udell (1998) concludes that financial needs and financing options available for SMEs are never static but rather change throughout the lifecycle of the organisation. That is the financing needs and opportunities in a growth stage of a firm may differ from that in a start-up stage. The proponents of the model also mentioned that since start-ups are faced with challenges such as informational opaqueness and lack of financial transaction history, SMEs during that stage of their lifecycle will usually depend on internal sources of finance (Abdulsaleh and Worthington, 2013). The paper looked at the above assertion in the context of the migrant family business under consideration.

In a more advanced stages of the growth cycle, when SMEs become more transparent in terms of provision of information, open with checkable business history, they may develop access to securitised debt and publicly listed equity markets (Berger\&Udell, 1998 as cited by Abdulsaleh and Worthington, 2013). The assertion here implies that information access by external parties of a business is really pivotal in determining the financing opportunity that may be available at every point in time of a business (Bhaird and Lucey, 2010).

Interestingly, Berger and Udell (1998) also conceded that the life cycle paradigm is not applicable to all SMEs operating in different industries implying that the firm size, age and information availability -which are intended to constitute the backbone of this particular paradigm- are not perfectly correlated. In other words, the factors mentioned above may not always determine financing trend of the SME (Abdulsaleh and Worthington, 2013). This paper also looked further than just the firm size, age and information availability and explored how 
social relations also affect financing decisions in order to help understand the financing strategies of a family SME which belongs to a migrant in the UK.

The pecking order theory which was first suggested by Donaldson in 1961 and modified by Stewart C. Myers and Nicolas Majluf in 1984 states that companies prioritize their sources of financing from Internal financing to external financing in other words preferring to explore the external finance as a last resort (Akbar, 2013; Cassar and Holmes, 2003 as cited by Abdulsaleh and Worthington, 2013) This theory considers a firm's age as an important function in determining the finance strategy especially for start ups. This paper explored the assertions of this theory and tried to find out how their social network may influence the finance decision choices.

The theory of planned behaviour have also emphasised the huge positive influence that family norms have on the finance decision making processes of family businesses (Ajzen, 1991 as cited by Kellermanns et al, 2014). A research that looked at over 100 family firms in Germany concluded that the values of the family businesses are what push them into favouring internal sources to external equity and loans. In other words, their conclusions favoured the pecking order theory and further deepened the notion that most family values were not in favour of external sources of finance and partnerships (Kellermanns et al, 2014). This paper looked at how family values affect a business owner's finance decision making processes especially in a migrant business setting. It further looked at how the network of the owners of the family affects its financing decisions.

\section{Financial Growth cycle}

\section{Pecking order Theory}
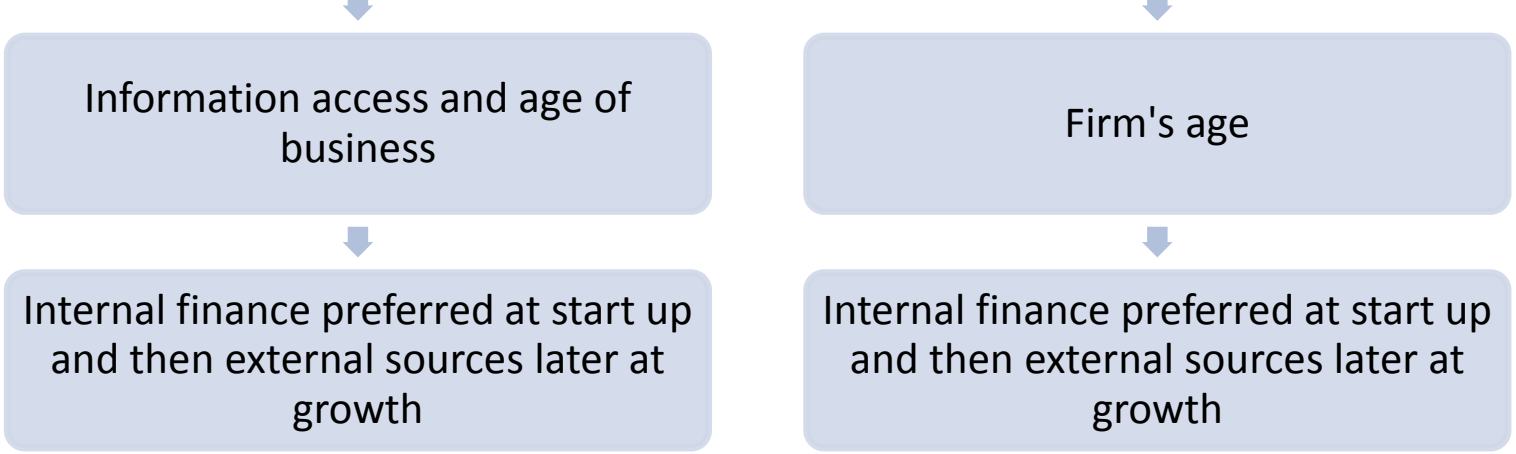


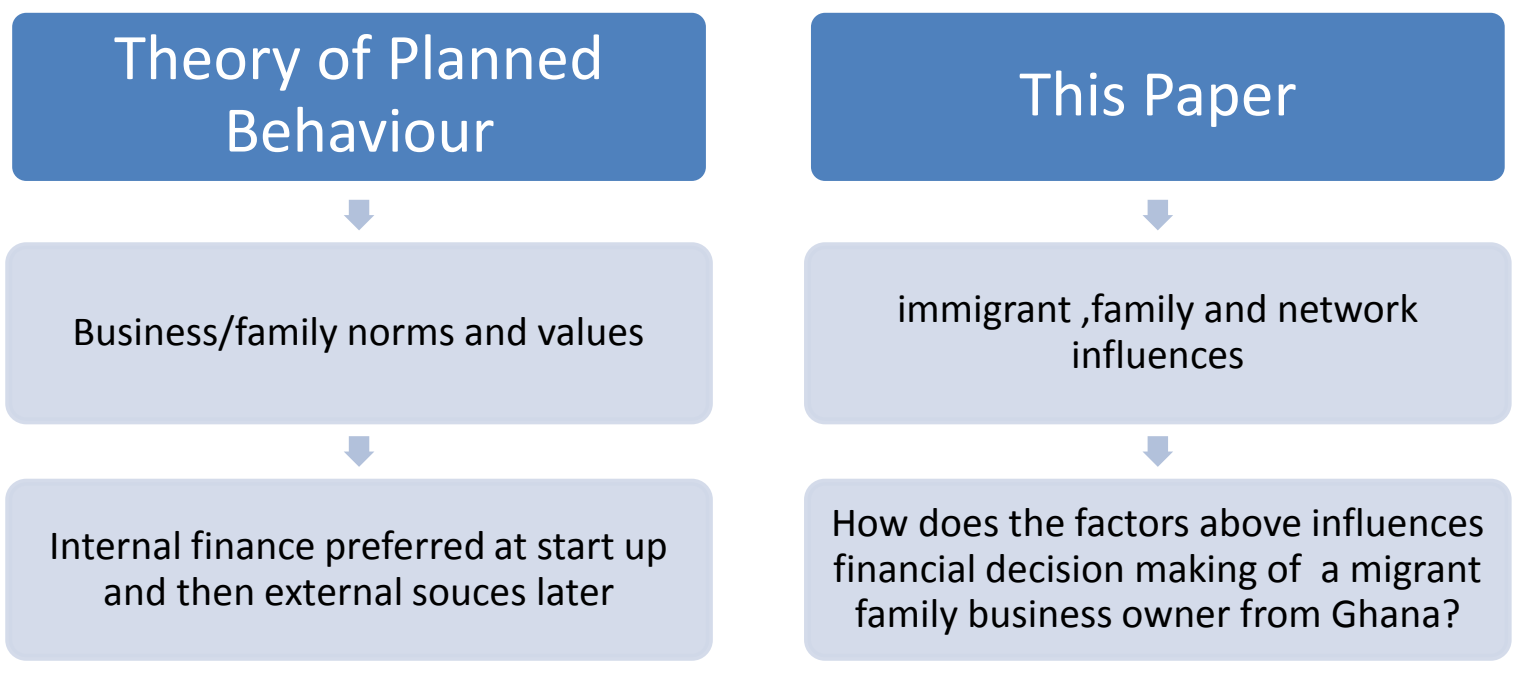

From the first three Flow charts above it is clear that the three theories discussed all concluded that businesses may prefer an internal source of finance especially at the initial stage of a business before consideration for an external source later when the business have grown or have had more informational accesses.

These conclusions were grounded on the assumptions that the businesses all had the same level of opportunities and influences all things being equal; but in the case of this paper, the financial decisions of a migrant family business from Ghana was looked at from the lenses of its network influences.

\subsection{Social Network Theory and Networks of Migrant Businesses:}

The Social network theory has been a popular theory in recent times in analysing various areas of studies such as business studies and social relations. The theory is based on the assumption that social relations are the key to explaining both individual and collective actions and outcomes. It is defined as a social structure made up of individuals (or organisations) called 'nodes' which are connected by specific types of interdependency such as friendship, Kinship, common interest, financial exchange, dislike, sexual relationships or relationships of beliefs and knowledge or prestige which are called 'ties' (Ozkan-Canbolat, 2014). The nodes which are the actors and ties (relationships) are very critical in any analysis. 
Entrepreneurs' especially migrant entrepreneurs require information, finance, skills set, and advice to start their business operations and most especially make financial decisions. Although the business owner(s) may possess some of the above mentioned needs, they may need the rest from their networks (Aldrich \& Zimmer, 1986; Aldrich, et al., 1991; Cooper, Folta, \& Woo, 1995; Hansen, 1995). The networks that are consulted in the process that helps the business owner to achieve his or her objective are the social capital .Burt (2000) has clearly established that an integral component of network interactions are the social capital that accrues to members within a defined network. "Social capital may be defined as those resources inherent in social relations that facilitate collective action. Social capital resources include trust, norms, and networks of association representing any group which gathers consistently for a common purpose" (Garson, 2006)

This study which looked for a lead as to how the financing decisions of a Ghanaian shop owner in Kent is undertaken then concentrated on the interactions between the shop owner and each of the members in her network. It is important to mention that social capital which is very integral to the Social network theory is usually reciprocally accrued within the relationships. The analysis focused on how the network identified interacted with the shop owner, reasons why they interacted and the level of closeness and connectedness between the group members. The analysis also looked at how weak or strong and reciprocal or directional the relationships were. To fully understand the activities of a particular network it is important to clearly define the network boundary under investigation. In the case of this paper, the network boundary identified were the family members, staff and social organisations. The boundary makes the shop owner at the centre of the network relating to the other relationships.

\subsection{Why Ghanaian family Businesses}

Entrepreneurship has been a hallmark of the Ghanaian culture even before the arrival of their 'colonial masters' (Takyi-Asiedu, 1993; Buame, 1996). In the everyday life of an average Ghanaian, there has been a time that they have found themselves involved in entrepreneurship in one way or the other. It is also important to mention that most of the businesses in Ghana are family based either directly or indirectly and therefore it is almost ineffective to properly analyse entrepreneurship in Ghana without linking it to their family settings (Robson et al, 2008). 
Inferring from the assertion above, it would have been logical for government support to be mostly channelled to these small businesses in Ghana, but it's unfortunate if not depressing to say that most of the historic and current government interventions and policies had focused on large and more formalised industries. Banks and other financial institutions have also prioritised export and import businesses at the detriment of small family businesses (Teal, 1998).

The background elaborated above have encouraged small firms in Ghana to continue to think 'small', set 'small' objectives and remain informal in order to continue to survive. It has also been observed that the development of small businesses in Ghana has been hindered by political interference, bureaucracy and corruption to the extent that policies meant for small businesses end up rather benefiting the relatively large businesses (Robson et al, 2008).

Additionally, the Government of Ghana in an effort to grow and develop the private sector and small and medium businesses in Ghana have put in so many systems and policies. In 2006 for instance the venture capital Trust fund was set up to aid businesses that may apply for debt financing as seed capital or for expansion of their businesses. Other systems set up by the Ghanaian government included the National Board for small-scale industries, the business assistance fund, Ghana Investment Fund and the rural enterprise project. Despite all these interventions, Small business owners and family businesses in Ghana still complain about inadequate accesses to finance and inadequate support (Yensu et al, 2015). This paper will therefore seek to know what informs these family business owners in their finance decision making in the UK context.

It is interesting to note that Ghanaian businesses as well as most African migrant businesses operating in the UK are so disadvantaged in terms of development, growth and financial access opportunities as compared to the Asian and other Europeans even with the opportunities and structures the UK government have established (Nwankwo,2005). This article therefore looked at why that trend and also ascertain whether the 'remain small mentality' explained above has a role to play in the financial decision making process of the Ghanaian entrepreneurs in the UK.

A World Bank study have also found out that about $90 \%$ of small enterprises surveyed stated that one of the main obstacles of doing business is access to finance (R. Parker, R. Riopelle, W. Steel, 1995). Most of the Ghanaian family businesses operating in the UK are small businesses in the context of the European Union that is operating with a balance sheet amount 
of less than 5 million euros and therefore the need to look at their situation and how their finance decisions are taken (European Union, 2008)

Apart from the World Bank study, most research has always mentioned small businesses in sub Saharan Africa as the worst culprits in terms of financing their businesses as already mentioned. For example a research have mentioned that a lot of businesses which operate in developing countries are usually affected with poor financing access but the worst are small and medium size family businesses as compared to large organisations (T. Beck, A. DemirgueKunt, L.laeven, V. Maksimovic, 2006 as cited by Yensu et al, 2015)

Also according to enterprise-level data by the World Bank of collected over a period of time, smaller and medium size family business in sub Saharan are more financially constrained than in any other developing region (Yensu et al, 2015) It is important for a business owner originating from such a geographical area to be critically looked at to ascertain how their finance decision making has been affected.

\subsection{Methodology:}

\subsection{Study Area}

The Kent area was chosen as our case study area looking at the blend of African migrants that reside there and also the willingness of a first generational Ghanaian to undertake the study.

\subsection{Respondent}

An in-depth face-to-face interview was conducted for a migrant Ghanaian family business owner in Kent and her narration was analysed in the context of the objectives of the paper. The author specifically looked for a Ghanaian shop owner who belongs to the first generation, migrated to the UK after the year 2000, operate a Small and medium enterprise and running the business as a family one. These criteria were important in order to achieve the objectives of the paper. A narration from the business owner was used for the analysis. 


\subsection{Research Instrument}

A detailed face-to-face interview was designed for the business owner. The themes for the interview included personal and family background questions, business background questions, finance access strategies questions and business growth aspiration questions. These thematic areas were analysed using the Social Network Theory.

\subsection{Discussion of Narration}

The findings of the interview are discussed in this section. The section will begin with the characteristics of the respondents, then its brief history, the business background and financing decisions, Business growth achievements and aspirations and finally the Conclusion and recommendation.

\subsection{Characteristics of the respondent}

Table 1 below summarises the personal characteristics of the shop owner

\begin{tabular}{|l|l|}
\hline Sample Characteristics & Items \\
\hline Gender of Shop owner & Female \\
\hline Age range & 41-55years \\
\hline Educational level(Highest) & High School \\
\hline Source of start up Capital & Personal Savings \\
\hline Marital status & Married \\
\hline Number of Children & 2 \\
\hline Status in the UK & Migrated to the UK in the year 2001 \\
\hline
\end{tabular}

\section{1a Start up history}

\begin{tabular}{|l|l|}
\hline Business Background (Questions) & Details (Response from the respondent) \\
\hline Business aim and Start date? & $\begin{array}{l}\text { "To have the time to look after kids whiles } \\
\text { making money to support the family. Started } \\
\text { in 2003" That implies that business was not } \\
\text { set to grow and expand. }\end{array}$ \\
\hline Main Goods sold at shop? & $\begin{array}{l}\text { "It used to be mostly Ghanaian food items } \\
\text { but later realised that most of the residents in } \\
\text { the geographical area (Kent) were Nigerians } \\
\text { and therefore have switched to mainly }\end{array}$ \\
\hline
\end{tabular}




\begin{tabular}{|c|c|}
\hline & $\begin{array}{l}\text { Nigerian food item" This was upon the } \\
\text { advice of the family which had a huge social } \\
\text { capital. }\end{array}$ \\
\hline $\begin{array}{l}\text { How initial Capital and working Capital } \\
\text { was raised? }\end{array}$ & $\begin{array}{l}\text { Initial capital was raised via personal savings } \\
\text { from taking a night ware house job. }\end{array}$ \\
\hline Any accesses to loans and credits? & $\begin{array}{l}\text { There were various offers for loans and credit } \\
\text { card facilities but her mum advised against it } \\
\text { whilst the husband encouraged that source of } \\
\text { financing. The shop owner agreed with the } \\
\text { mum because the interest payment could } \\
\text { swallow all the profits. This suggested that } \\
\text { the shop owner listened to the mum more } \\
\text { than the husband and therefore valued the } \\
\text { social capital of her mum as compared to her } \\
\text { husband even though they are all family. }\end{array}$ \\
\hline Who advices you on financing decisions? & $\begin{array}{l}\text { "Mum, Husband and a friend whom we both } \\
\text { belong to a Ghanaian community group". } \\
\text { Looking at the narration so far it is clear that } \\
\text { the mum was the most important in terms of } \\
\text { the members of the family's advice. }\end{array}$ \\
\hline $\begin{array}{l}\text { How are you connected to the Ghanaian } \\
\text { group? }\end{array}$ & $\begin{array}{l}\text { "I just sponsor them as and when they may } \\
\text { need my help. I do not attend meetings". }\end{array}$ \\
\hline Social Network? & $\begin{array}{l}\text { Belongs to a Ghanaian association called } \\
\text { Ghana Ba. "I have a friend there who also } \\
\text { advices me on the business decisions just } \\
\text { because of his experience in the past. She } \\
\text { was a part of the group of the social capital } \\
\text { she expects from the members of the group" }\end{array}$ \\
\hline
\end{tabular}

The shop under study which deals with African and Asian food stuff was started in the year 2003. The motivation for the start of the family business which belongs to a wife was for her to have time for the Kids at home since the shop is located close to their home. Additionally, it 
was a business that the owner was undertaking in Ghana before migrating to the UK. The day to day running of the business is done by the owner with some help from their children.

Within the first two years of the business the shop owner was working in a warehouse in the night in order to help accrue more capital. This strategy was coined by the shop owner's mum who financed her businesses with the same strategy in Ghana. The narration is therefore in line with the pecking order theory and the theory of planned behaviour. The respondent also mentioned that she consulted the husband and other African community members in the area about how her migration status could affect her financial decisions and assessments. This may point to the fact that apart from the family network the respondent also viewed the African community as a form of social capital in terms of providing advice on how to go about financial decisions.

\subsection{Narration on financing decisions and trends}

The respondent mentioned that she was interested in exploring the financial assistance platforms provided in the UK when she started her operations but had heard about the difficulty in accessing such platforms from her networks (Constantinidis et al, 2006). This assertion gives some credence to the perception migrant businesses have about the difficulty in assessing financial assistance platforms in the UK (Santos and Silvester, 2016: Nwankwo, 2005).

She further elaborated that with all the negative perceptions around migrant business financing, her husband advised her to get a facility from a bank but she rather decided to go by her mum's advice not to seek for any financial assistance in the start up and growing stage of business. She further mentioned that her mum said she was successful when she decided to run a shop in Ghana without external finance and therefore that advice. This clearly indicates that there was a transfer of strategy from their home country of Ghana. Also the values and principles of the family played an integral role in the decision as per the narration above because her mum's values highly influenced the final financing and start up strategy (Koropp et al, 2014). Finally, it could be deduced from the narration that the business owner preferred a use personal and family savings at the start of the business (Fatoki, 2014).

The shop owner's highest educational achievement was up to the high school level and this may have also defined her understanding of the various financing options and opportunities and therefore limiting their financing options and growth aspirations. This conclusion may be 
in line with a research that detected the relationship between educational background of decision makers and that of their educational background. The paper concluded that business decision makers with a high educational background will usually explore more feasible options (Nwankwo, 2005). In the case of this study, it was also realised that the negative perception around financing by banks in the UK also adversely affected the shop owner in avoiding the external sources and banks.

The status in the UK as a migrant did not in any way affect her chance to access finance because she mentioned that she was and is still approached by the financial agencies to check if she needed assistance. This assertion goes a long way to buttress a certain research undertaken in Germany where reasons ascribed for the relatively less financial assistance to migrant businesses were stemmed from differences in risk factors and financial relationships and not that of ethnicity (Bruder et al, 2011).

\subsection{Narration on Financial Decisions and Social Networks}

From the narration above it can be suggested that the family business owner depended on four major factors and circumstances for financing advice and decisions. These factors were the personal characteristic which is more of a mitigating factor, family, migration status and Ghanaian social group. The diagram ' $A$ ' below shows the identified networks which is a dependent variable in the analysis. It was also evident that the influence of the various factors had varying strength in terms of the effect on the decision maker which is the business owner. From the narration it can be suggested that one or more of the identified networks was considered in the financial decision making process as shown in diagram B.

From the narration the following identified networks were considered in the decision making process.

\subsection{Identified Network: Dependent Variable}

The identified network size refers to all the contacts that the business owner comes into contact with in making his or her financial decisions irrespective of the type of interaction. For the purposes of this paper, we refer to this subset of the contacts as identified networks. 
To make financial decisions, firms and/or potential entrepreneurs look for contacts with common interest or experience who have partaken in the same or similar decision making processes (Nohria, 1992).By limiting our focus to the identified networks, we will focus on social capital that was accrued from the identified networks. The identified network below was selected based on the narration of the shop owner.

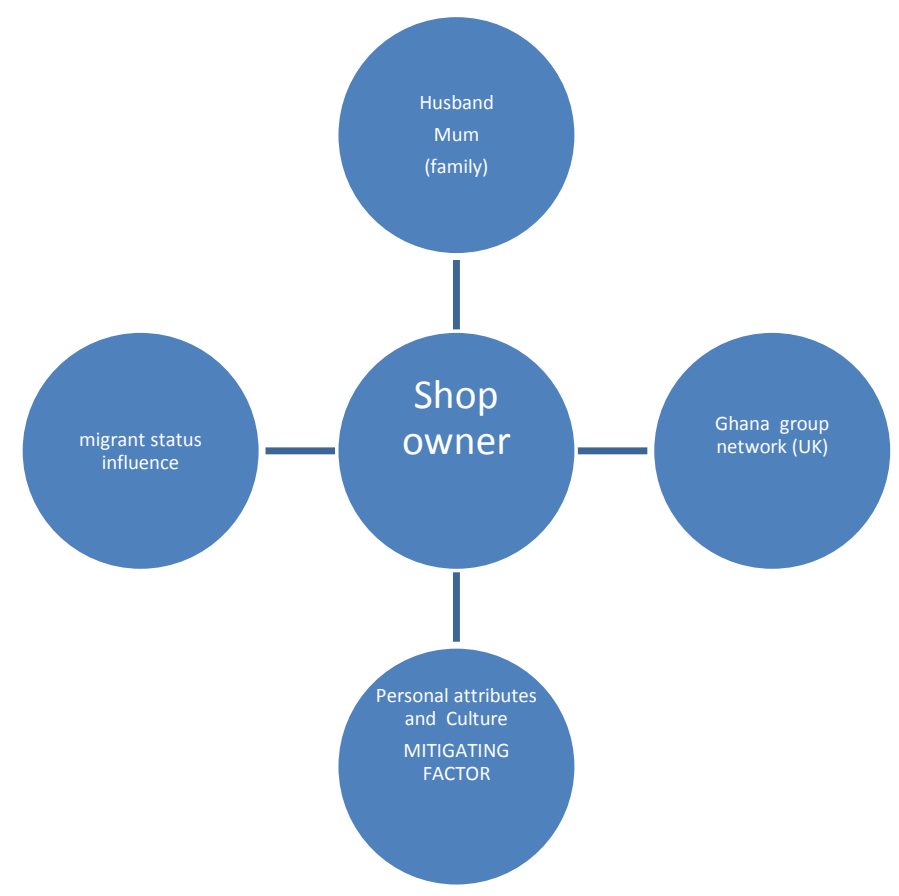

\section{Diagram A}

\subsection{Financial decision-making process: Independent Variable}

The financial decision making process as stipulated in the diagram below which have the business owner depending on a certain relationship and 'expected' social capital in the decision making process. These are what this paper will basically look at not forgetting the business growth aspirations associated with such relationships. The independent variable will be analysed from the process of determining current financial situation through to the review and revision of a financial plan. 
Looking at the consideration of the alternative courses of action, the shop owner consulted her closest family members whom she believed could accrue to her the most social capital in that perspective. The financial planning process discussion below also states the identified network contacted during each of the decision making processes.

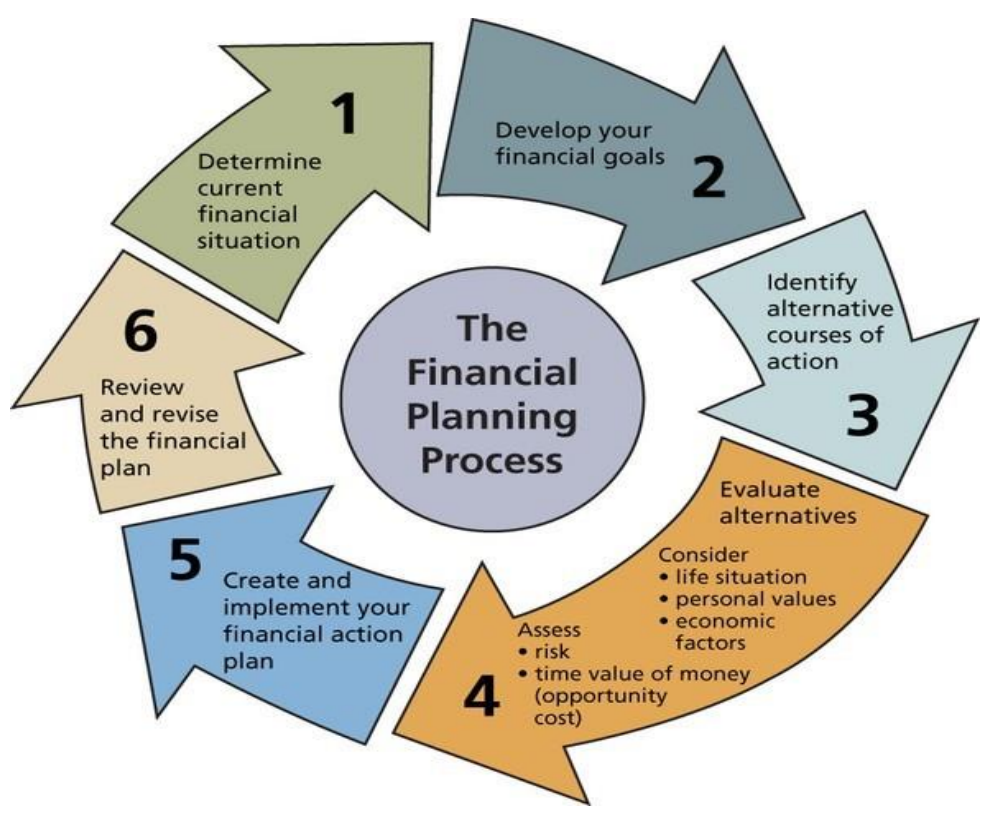

\section{Diagram B}

1. Determine current financial situation: family, personal attributes \& culture and migrant status and influence.

2. Develop financial goals: family and personal attributes \& culture.

3. Identify alternative courses of action: family, personal attributes \& culture, migrant status and influence and Ghana group networks

4. Evaluate alternatives: family, personal attributes \& culture and Ghana group networks

5. Create and implement financial action plan: family and personal attributes

6. Review and revise the financial plan: family and personal attributes 
It can be suggested from the above narration that the family had the most influence and social capital in terms of financing decisions followed by the personal characteristics and culture and then the migrant status and Ghana group network respectively. It was clear that the shop owner had set out not to take any external finance due to the advice given by her mum. That mindset also discouraged her from exploring avenues that could provide her with financial support for her business growth. It is therefore comfortable to say that the narration so far points to the family as one of the main factors for the accrual of Social Capital.

It can also be suggested that apart from the family that had the most influence and social capital throughout the decision making process, the personal attributes and culture mitigated the factors throughout the process. The culture of self financing your business start up and operations did not encourage growth. Although this self-financing mentality worked perfectly for the shop owner at the growth stage of the business during the study, it was realised that the time it took the business some time to realise the capital of $30,000 \mathrm{GBP}$ during the interview which is in line with financial growth cycle discussed above. The shop owner was therefore satisfied with the growth of the business even though she could have done better with a financial support from the financial institutions during the start up stages.

Initially the migrant status as a foreigner adversely affected their push to go for a loan to start up the business because she said she felt she was new in the country and might not have the right documentation and credit score to get a loan or credit card to do her business which is in line with an assertion made by Santos and Silvester (Santos and Silvester, 2016). She also mentioned that she was asked not to go for any loan as it will be rejected which could subsequently affect her credit score. This advice came from the Ghanaian group members she belonged to.

There were also no intentions to start up the business using finance from 'external' institutions which confirms the pecking order theory discussed above. The reasons ascribed for such obvious snub was the fear of high interest rates which may swallow profits which has been the case from the owner's country of origin.

Although it was observed the interest rate in Ghana was relatively high as compared to the UK, the mere fear of high interests in Ghana had adversely affected the business owner in the UK to even make a move and go forward to enquire and compare. Again it can be suggested that the social capital from the mum of the shop owner was not taken for granted and also the strength of the ties between the family in general\& the shop owner's personal attributes and 
the shop owner was very strong as compared to the weak ties between the shop owner and the Ghanaian network groups.

\subsection{Business Growth achievements and aspirations}

The business owner stated that she thinks the business has really grown because the business started in 2003 with an initial capital of $£ 2500$ but now have a capital of about $£ 30,000$ after 14 years of operations. She said she was happy with the growth situation of the business. Her secret for the growth is the fact that she tries to manage the business well herself without depending so much on hired staff.

She also mentioned that she knew other shop owners who handed the running of the shop to employees and saw the business collapse. She hoped the business will be closed in the next 5 years because by then her kids would have grown enough to take good care of themselves. She did not have any plans of expansion because employees may steal from her. She always believed in running the business herself. It can be suggested that her perception of the business growth aspirations is based on her personal attributes and culture. The mindset espoused above has also indicated why such businesses may not grow as expected.

Business growth aspirations was only limited to doing business and making enough profit to support the family. There was no aspiration of growing the business to a large business. The business growth agenda of the business was not planned beyond 2 years. The shop owner had only very short term plans and aspirations for the business. Looking at the narrative of the Ghanaian Migrant business owner, it was clear that the main objective for setting up the business was not to grow the business and the economy but doing business just to support the family and also have the chance to take care of her kids at home.

\subsection{Conclusion and Recommendation}


From the narration it can be recommended that policies that are designed to help migrant family businesses in the UK should not be done in general but should be done to suit the unique culture and characteristics of the business owner and family. This is because from the narration it can be suggested that family, personal attributes and culture had the most social capital for the shop owner to use or explore in taking her financial decisions. Family values and beliefs also played an important role in determining the financial direction and strategy of the business.

It also came to light that the UK financial system although not very effective in helping migrant start up businesses, they are usually open to help grow the business once it takes off smoothly. Interestingly research have proved that the more a firm increases in size and information availability, the more financial institutions are open to offer assistance and support but in the case of this study the respondent did not have to disclose much information to the institutions but her sales levels and bank savings was what the banks used as a base to offer the financial assistance that was rejected by the shop owner.

It was also realised from the narration that apart from family members been an integral source of finance to small migrant businesses as proved in the literature review as well it can also be suggested that these family members and sources are also very participatory and active in the financial decision making and strategies of a family member's business irrespective of whether they are sources of finance to the business or not.

Although the discussions in this writing did not lead to a full picture, it provided an experience and framework which is a good starting point for future theoretical and empirical works. The author believes that further research in this area where by more respondents are interviewed could through more light on the topic and bring more clarity to the specific research area.

\section{REFERENCES:}

Abdulsaleh, A. And Worthington, A. (2013) 'Small and Medium-sized Enterprises Financing: A review of literature' International Journal of Business and Management Vol 8, No.14 Available from: http://dx.doi.org/10.5539/ijbm.v8n14p36 (Accessed: 15 April 2017). 
Altinay, L. (2008) "The relationship between an entrepreneur's culture and the entrepreneurial behaviour of the firm", Journal of Small Business and Enterprise Development, Vol.15 Issue: 1, pp.111-129, https://doi.org/10.1108/14626000810850874 AnnaMotylska-Kuzma, (2017) "The financial decisions of family businesses", Journal of Family Business Management, Vol. 7 Issue: 3, pp.351-373, https://doi.org/10.1108/JFBM$\underline{07-2017-001}$

Akbar, A. (2013) Pecking order theory [online] Available From:http://www.slideshare.net/alvinakbar5/pecking-order-theoryfinance(Accessed: $\quad 12$ August 2016)

Borgatti, S. and Halgin, D.,(2011) 'On Network Theory' Available From: http://dx.doi.org/10.2139/ssrn.2260993 (Accessed: 15 August 207)

Bruder,J., Neuberger,D.,Räthke-Döppner,S., (2011) "Financial constraints of ethnic entrepreneurship: evidence from Germany", International Journal of Entrepreneurial Behavior \& Research, Vol. 17 Issue: 3, pp.296-313 Available from: https://doi.org/10.1108/13552551111130727

Buame, SK (1996) Entrepreneurship: A Contextual Perspective. Discourses and Praxis of Entrepreneurial Activities within the Institutional Context of Ghana. Lund: Lund University Press

Burt, R. (2000) 'The Network Structure of Social Capital' Research in Organisational Behaviour Vol.27 pages 345-423

Carter, S. (2015) 'Supporting ethnic minority and female entrepreneurs' [online] Available From:http://www.esrc.ac.uk/news-events-and-publications/evidence-briefings/supportingethnic-minority-and-female-entrepreneurs/ (Accessed: 10 August 2016)

Carter, S., Mwaura, S., Ram, M., Trehan, K and Jones, T. (2015) 'Barriers to ethnic minority and women's enterprise: Existing evidence, policy tensions and unsettled questions' [online] International Small Business Journal 2015 Vol33(1) 49-69 Available From: http://isb.sagepub.com/content/33/1/49.short (Accessed: 11 August 2016)

Constantinidis, C., Cornet, A., and Asandei, S. (2006)' Financing of Women-owned ventures: The impact of gender and other owner -and firm-related variables, Venture Capital 8:02, 133-157[online] Available From: DOI: 10.1080/13691060600572557 (Accessed: 10 January 2017)

Daskalakis, N., Jarvis, R. Schizas, E. (2013) "Financing practices and preferences for micro and small firms", Journal of Small Business and Enterprise Development, Vol. 20 Issue: 1, pp.80-101, https://doi.org/10.1108/14626001311298420 
Department of communities and local Government (2013) Ethnic minority business and access to finance [online] Available from: https://www.gov.uk/government/uploads/system/uploads/attachment_data/file/225762/EMBs and_Access_to_Finance.pdf (Accessed: 10 August 2016)

Dhaliwal, S. (2008) 'Business support and minority ethnic businesses: Asian, Korean and African-carribean businesses in England' [online] Available From: http://epubs.surrey.ac.uk/178666/2/FMEB_UK.pdf (Accessed: 10 August 2016)

European Commission (2003) what is SME[online] Available from:http://ec.europa.eu/growth/smes/business-friendly-environment/sme-definition_en (Accessed: 10 September 2016)

Fatoki, O. (2014) 'The financing preferences of immigrant small business owners in South Africa" Mediterranean Journal of Social Sciences Vol5, No20.

Garson, G.D. (2006) 'what is social capital' [online]

Available from: https://sites.hks.harvard.edu/saguaro/web\%20docs/GarsonSK06syllabus.htm (Accessed: 11 October 2017)

Gupte, R., Venkataramani, B., Gupta, D.(2012) 'Computation of Financial Inclusion Index for India’ Procedia - Social and Behavioural Sciences, Volume 37, 2012, Pages 133-149 [online] AvailableFrom:http://www.sciencedirect.com/science/article/pii/S1877042812007604 (Accessed: 15 August 2016)

Hughes, A. (1997) 'Finance for SMEs: A UK Perspective' [online] Small Business Economics, Vol. 9, No. 2, European SME Financing: An Overview (Apr., 1997), pp. 151-166 Published by: Springer Available From: http://www.jstor.org/stable/40228637 (Accessed: 10 July 2016)

Hussain, J .andMatlay,H. (2007) "Financing preferences of ethnic minority owner/managers in the UK", Journal of Small Business and Enterprise Development, Vol. 14 Issue:3, pp.487-500, https://doi.org/10.1108/14626000710773565

Koropp, C., Kellermanns, F.W., Grichnik, D., Stanley, L. (2014) 'Financial Decision Making in Family firms: An adaptation of the theory of planned behaviour' Family business reviewVol.27 (4) 307-324 Available From: http://fbr.sagepub.com/content/27/4/307.refs.html

(Accessed: 20 April 2017)

Moss, S. (2016) Theory of planned behaviour [online] Available From: http://www.sicotests.com/psyarticle.asp?id=69 (Accessed: 11 August 2016)

Obeng, B.A., Robson, P. and Haugh, H. (2012) 'Strategic entrepreneurship and small firm growth in Ghana' [online] International small business Journal August 2014 vol.32 no.5 501524 Available From: http://isb.sagepub.com/content/32/5/501.short (Accessed: 12 August 2016) 
Ozkan-Canbolat, E. (2014) 'Organizational Network effect on Diversification Strategies' Strategic Management Quarterly Vol2, No2, pp.27-48

Quartey, P. (2003) 'Financing small and medium enterprises in Ghana' Journal of African BusinessVol 4(1) [online] Available From: http://www.haworthpressinc.com/store/product.asp?sku=J156 (Accessed: 10 August 2016)

Santos, R. and Silvester, A. (2016) 'Migrant Entrepreneurship in the UK' Available From:https://www.iod.com/Portals/0/PDFs/Campaigns\%20and\%20Reports/Start\%20ups/Mig rant-entrepreneurship-report.pdf?ver=2016-09-09-161348-390 (Accessed: 25 April 2017)

Sarbah and Wen (2013) Financing family businesses in Ghana: Challenges and the way forward [online] Available From: file://C:/Documents\%20and\%20Settings/user/Desktop/FAMILY\%20BUSINESS\%20RESE ARCH/Source\%20of\%20Financing\%20Family\%20Business.pdf

(Accessed: 26 July 2016)

Sarbah and Wen (2014) Corporate Governance practices in Ghanaian family businesses: A conceptual framework [online] Available From: file:///C:/Documents\%20and\%20Settings/user/Desktop/FAMILY\%20BUSINESS\%20RESE ARCH/Corporate-Governance-Practices-in-Ghanaian-Family.pdf(Accessed: 15 July 2016)

Seaman, C., McQuaid, R. and Pearson, M. (2014) 'Networks in family business: a multirational approach' International entrepreneurial Management Journal (2014) 10: 523-537 [online] Available From: http://link.springer.com/article/10.1007/s11365-014-0297-4 (Accessed: 12 August 2016)

Silva, M. (2013) The Latin American Enterpreneur in the United Kingdom: An exploration of the factors driving the formation of the migrant enclave economy and its influence on the community [online] Available From: http://etheses.qmu.ac.uk/1599/1/1599.pdf (Accessed: 12 May 2016)

Takyi-Asiedu, S. (1993) 'Some socio-cultural factors retarding entrepreneurial activity in subSaharan Africa' Journal of Business Venturing Vol8, issue 2, 91-98.

Williams, D. (2010) 'An Empirical Investigation into the Financing of Small, Family-owned Businesses in Jamaica' [online] Social and Economic Studies, Vol. 59, No. 3, Special Focus on Women- and Family-Owned Businesses in the Caribbean (September 2010), pp. 3157Published by: Sir Arthur Lewis Institute of Social and Economic Studies, University of the West Indies Available From: http://www.jstor.org/stable/41803637?seq=1\&cid=pdf-

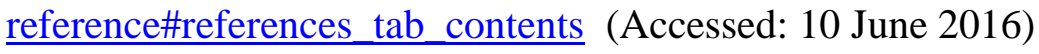

Yensu, J., Oppong-Peprah, E.,Dwomo-Fokuo, E., Boadu, F., Kusi, A. Financing the Expansion of Family Businesses in Ghana: Which Way to Go, Debt or Equity[online]. Journal of Investment and Management. Vol. 4, No. 6, 2015, pp. 301-310. Available from: http://article.sciencepublishinggroup.com/pdf/10.11648.j.jim.20150406.13.pdf 
(Accessed: 12 July 2017) 